\title{
Restorative Justice and Procedural Justice: Dealing with Rule Breaking
}

\author{
Tom R. Tyler* \\ New York University
}

This article identifies similarities among three approaches to dealing with rule breaking: the procedural justice model, the restorative justice model, and the study of moral development. Each argues that the long-term goal when dealing with rule breaking is to motivate rule breakers to become more self-regulating in their future conduct. This goal is undermined by punishment-focused models of sanctioning. Sanction-based models, which dominate current thinking about managing criminals, have negative consequences for the individual wrongdoer and for society. It is argued that greater focus needs to be placed on psychological approaches whose goal is to connect with and activate internal values within wrongdoers with the goal of encouraging self-regulatory law-related behavior in the future.

In the last several decades, America could perhaps best be characterized as a highly "punitive" society (Roberts \& Stalans, 2000; Tyler, Boeckmann, Smith, \& Huo, 1997; Whitman, 2003). The focus of public attention has been on the need to punish rule-breakers and support has been high for harsh punishments for a wide variety of crimes, punishments including the death penalty and life in prison. The general tenor of recent times is captured by the case of support for the death penalty. During the 1960s, a majority of adult Americans favored ending the death penalty, while public opinion polls during the 1980s-1990s typically found that $80 \%$ or more of those interviewed favored the death penalty (Ellsworth \& Gross, 1994). The focus of public discussion has been, in this and many other ways, on the view that the legal system is too lenient and that there need to be harsher ways to punish those who commit crimes.

These punitive aspects of American culture are striking because they have become stronger during recent decades. A person looking at American society in

\footnotetext{
* Correspondence concerning this article should be addressed to Tom R. Tyler, Department of Psychology, New York University, 6 Washington Place, Room 579, New York, NY 10003 [e-mail: tom.tyler@nyu.edu].
} 
the 1960s might have projected a future of declining punishment and increasing efforts at rehabilitation and reintegration for offenders (Garland, 2001). For example, during the 1960s the majority of adult Americans opposed the death penalty, the result of steady declines in support since the 1930s. That is, in fact, the direction taken by much of Europe (Whitman, 2003). However, the United States has not moved in that direction. Instead, it has become a more punitive society in which harsh punishment is central to reactions to rule breaking (Garland, 2001; Whitman, 2003).

Central to this punitive society is a model in which the primary way of motivating compliance with the law is via the application of sanctions. There have been several negative consequences of this sanction orientation. One is that it has led to a swelling of the prison population, with the result that America is now one of the leading countries in the world in terms of the proportion of its adult population held in jails and prisons (Haney \& Zimbardo, 1998). This statistic itself does not capture the true impact of the large prison population. That impact has been disproportionately upon the poor and minorities whose communities have been decimated, as large numbers of young minority males have spent time in prisons.

In addition, this punitive orientation toward the population has made more negative the relationship between the police, courts, and the residents of American communities (Tyler, 1997, 1998; Tyler \& Huo, 2002). In an effort to lessen serious crime, for example, the New York city police have punished more severely minor crimes, such as drinking in public parks. Instead of receiving a minor penalty for such crimes, people have been brought into police stations, booked, and held in jail overnight. In recent years, this has led to punitive experiences, including being jailed overnight or for weekends, for a much larger proportion of the cities' youth than in past years (Tyler \& Huo, 2002), with resulting hostility toward the police. While not the only punitive policy enacted by police, this approach to social control typifies the use of force to secure compliance, and the public hostility that results. Many legal authorities acknowledge these negative consequences, but regard them as the inevitable byproducts of engaging in effective social regulation (Nagin, 1998).

\section{Other Approaches}

Procedural justice research suggests that there is another possible route to effective social regulation besides punitive punishment (Tyler, 1990; Tyler \& Huo, 2002). This route involves treating people with procedural justice and respect. When people are so treated, they view law and legal authorities as more legitimate and entitled to be obeyed. As a result, people become self-regulating, taking on the personal responsibility for following social rules. This approach has been labeled a process-based model of regulation (Tyler, 2003, 2006). 
These procedural justice findings can be put within a larger framework of social engagement, in which we seek to understand how to constructively engage people in society and social institutions. Research suggests that the key to doing so is to create groups, organizations, and societies within which people experience procedural justice (Tyler, 1990; Tyler \& Blader, 2000; Tyler \& Huo, 2002). Two types of procedural justice are key: justice in the quality of decision-making procedures and justice in the quality of treatment that people receive from others. When people experience these forms of justice, they are found to accept social rules, and voluntarily engage in self-regulatory behavior (Tyler \& Blader, 2000; Tyler \& Huo, 2002).

The importance of procedural justice research is that its findings point to the potential viability of models of regulation that rely upon self-regulatory motivations. Research suggests that people will obey laws, without the threat of sanctions, when they experience the criminal justice system and its authorities as acting justly. Hence, there are viable models of proactive social regulation that do not generate the negative consequences associated with punitive, sanctioning, approaches to rule breaking.

The goal of this review is to point to common elements shared by this procedural justice approach, the restorative justice movement, and a focus on morality and moral development. These approaches are united by their common goal: to encourage the development or activation of people's internal values so that they will become more motivated to engage in self-regulatory behavior. It is suggested that a civil society is most effective when its members buy into commonly held values and follow rules because they are motivated to do so, rather than because they are motivated by incentives or sanctions.

\section{Shaping People's Behavior}

The roots of these approaches lie in an analysis of the nature of human motivation. Kurt Lewin (Gold, 1999) distinguished between two core elements in human motivation. One source of motivation is the basic desire to maximize gain and minimize loss in interactions with others. These are "instrumental" or "self-interested" motivations. The underlying assumption of Lewin's model of motivation is that shaping the external environment by providing incentives or threatening sanctions is one way to shape people's behaviors. This model of motivation is frequently referred to as the deterrence or social control model (Nagin, 1998), and it has dominated American thinking about how to control crime during the last several decades.

Such models focus on the ability of legal authorities and institutions to shape people's behavior by threatening to deliver or by actually delivering negative sanctions for rule breaking. To implement such deterrence strategies, police officers carry guns and clubs, and can threaten citizens with physical injury, incapacitation, 
or financial penalties. Their goal is to establish their authority and "The uniform, badge, truncheon, and arms all may play a role in asserting authority" in the effort to "gain control of the situation (Reiss, 1971, p. 46)." The police seek to control the individual's behavior "by manipulating an individual's calculus regarding whether "crime pays" in the particular instance (Meares, 2000, p. 396)." Judges similarly shape people's acceptance of their decisions by threatening fines or even jail time for failure to comply.

Research suggests that the ability to threaten and/or deliver sanctions is often effective in shaping people's law-related behavior (Nagin, 1998). In particular, a number of studies on deterrence suggest that people are less likely to engage in illegal behaviors when they think that they might be caught and punished for wrongdoing (Nagin \& Paternoster, 1991; Paternoster, 1987, 1989; Paternoster \& Iovanni, 1986; Paternoster, Saltzman, Waldo, \& Chiricos, 1983; Tyler, 1990). This core premise of deterrence models is supported by many, but not all, studies examining the factors that shape people's law-related behavior (Nagin, 1998; Tyler, 1990).

Studies of deterrence also point to several factors that limit the likely effectiveness of deterrence models of social regulation. Perhaps the key factor limiting the value of deterrence strategies is the consistent finding that deterrence effects, when they are found, are small in magnitude. For example, in a review of studies of deterrence in the area of drug use, MacCoun (1993) finds that around 5\% of the variance in drug use behavior can be explained by variations in the expected likelihood and/or severity of punishment. This suggests that much of the variance in law-related behavior flows from other factors besides risk estimates.

Some of the difficulties associated with deterrence approaches are the result of the fact, established by deterrence research (see Nagin, 1998), that it is the perception of the certainty of punishment, rather than its severity, that most strongly shapes behavior. One consequence of this is that deterrence approaches are costly, because certainty of punishment is shaped by the deployment of police resources. Political leaders are attracted to severe punishments, such as the death penalty, in part because it is not expensive to implement such policies. Unfortunately, from a cost perspective, these severe punishments are not especially effective deterrents of crime (see Ellsworth \& Gross, 1994). Given the realities of democratic societies, in which policing and surveillance are low, the probability of being detected when breaking many laws is low (Tyler, 1990). This makes deterrence based upon the probability of being detected for wrongdoing a poor strategy under many circumstances.

To have a more effective strategy for dealing with the issue of public compliance, we would benefit from being in a situation in which people have additional reasons for obeying the law beyond their fear of being caught and punished for wrongdoing (Sherman, 1993, 1998, 1999; Tyler, 1990). It is to such additional motivations that procedural justice approaches are directed. This need for additional 
motivations has also been recognized in recent discussions of deterrence theory, which include extralegal factors such as morality and informal social control (see Foglia, 1997; Grasmic \& Bursik, 1990; Nagin \& Pogarsky, 2001).

\section{Internal Motivations}

Lewin contrasts the influence of external contingencies to the influence of internal motivations (Gold, 1999). There are many types of internal motivations. One set is linked to things that people want to do-i.e., to their attitudes. For example, people are intrinsically motivated to engage in actions that they enjoy. Further, people are motivated to act on behalf of groups and people to whom they feel committed. The second set of internal motivations is linked to feelings of social obligation. These motivations reflect people's willingness to act based on feelings of social values that reflect feelings of social responsibility. Two such values are important: legitimacy and morality (Tyler \& Blader, 2005).

Legitimacy from this social value perspective is the property that a rule or an authority has when others feel obligated to voluntarily defer to that rule or authority (Tyler, 1990, 2006). In other words, a legitimate authority is an authority regarded by people as entitled to have their decisions and rules accepted and followed by others (French \& Raven, 1959). The roots of the modern discussion of legitimacy are usually traced by the important writings of Weber on authority and the social dynamics of authority (Weber, 1968).

Weber argues that the ability to issue commands that will be obeyed does not rest solely upon the possession and ability to use power. In addition, there are rules that people will voluntary obey, and authorities whose directives will be voluntarily followed. Legitimacy, therefore, is a quality possessed by an authority, a law, or an institution that leads others to feel obligated to obey its decisions and directives. It is "a quality attributed to a regime by a population (Merelman, 1966, p. 548)."

This feeling of responsibility reflects a willingness to suspend personal considerations of self-interest and to ignore personal moral values because a person thinks that an authority or a rule is entitled to determine appropriate behavior within a given situation or situations.

Kelman and Hamilton (1989) refer to legitimacy as "authorization" to reflect the idea that a person authorizes an authority to determine appropriate behavior within some situation, and then feels obligated to follow the directives or rules that authority establishes. As they indicate, the authorization of actions by authorities "seem[s] to carry automatic justification for them. Behaviorally, authorization obviates the necessity of making judgments or choices. Not only do normal moral principles become inoperative, but—particularly when the actions are explicitly ordered-a different type of morality, linked to the duty to obey superior orders, tends to take over (Kelman \& Hamilton, 1989, p. 16)." 
One way to think about legitimacy is as a property of an institution or group of authorities. For example, studies of confidence in government ask people to rate the overall government, and its institutions and authorities. Studies of the legitimacy of legal authorities similarly ask people to evaluate their general feelings of responsibility and obligation to obey the law and legal authorities (see Tyler, 1990).

Does the social value of legitimacy matter? Tyler (1990) examined this issue in a study of the law-related behavior and found that legitimacy shaped everyday compliance with the law, a conclusion supported by more recent studies (Sunshine \& Tyler, 2003a). Further, legitimacy had more influence on compliance than did sanction risks. Hence, evidence suggests that internal values, at least the internal value of legitimacy, shape law-related behavior (Tyler, 1990; Tyler \& Huo, 2002). So, our ability to shape such behavior would improve if we could understand how to activate these motivations.

One way to encourage people to view law as legitimate is for legal authorities to act in procedurally just ways. For example, studies suggest that procedural justice during personal experiences with authorities is important because it builds the social value of legitimacy (Tyler, 2004). Legitimacy, once activated, then encourages everyday compliance with the law. Hence, legal authorities receive more citizen cooperation when people generally view them as legitimate. People, who have more supportive social values, are easier for legal authorities to deal with during personal encounters.

Beyond particular experiences, people are generally more likely to regard the police as legitimate if they believe that the police exercise their authority through fair procedures (Sunshine \& Tyler, 2003a; Tyler, 2001). As people develop supportive social values such as legitimacy, they are more willing to defer to particular legal authorities (Tyler \& Huo, 2002), and also generally more compliant with the law (Sunshine \& Tyler, 2003a; Tyler, 1990). These general procedural justice judgments are more central to legitimacy than are evaluations of the effectiveness of the police in combating crime.

The discussion of legitimacy makes clear that people's internal values have an important role in shaping their behavior. Hence, the legal system gains when those values are engaged and support self-regulatory or internal motivations toward complying with the law and with the directives of legal authorities. To encourage such a value-based reaction to authorities, it is important for the police and courts to act in ways that people view as reflecting procedural justice.

This focus on the importance of legitimacy reflects the legacy of Weber (1968), who was concerned with the circumstances under which people follow the directives of social rules and social authorities. Legitimacy is important to the success of such authorities because they are enabled to gain public deference to a range of decisions by virtue of their social role. This deference is not unlimited, because legitimacy may exist within a certain sphere, but within that sphere, acceptance of 
the right of authorities to make decisions that ought to be accepted and obeyed is broad.

Experiencing procedural justice, either in particular personal experience or in the everyday functioning of the law, is important because it encourages feelings of responsibility and obligation to follow the law-i.e., it increases the legitimacy of the law and the legal system. Hence, procedural justice suggests that possibility of a legal system based more heavily upon voluntary cooperation-of processbased regulation (Tyler \& Huo, 2002; Tyler \& Sunshine, 2003a).

\section{The Morality of the Law}

Legitimacy is not the only social value upon which the legal system might potentially be based. A second social value is personal morality-the motivation to behave in accord with one's sense of what is appropriate and right to do in a given situation. For example, people may think that using drugs is morally right or wrong, irrespective of whether drug use is illegal. These feelings about the morality of particular behaviors also shape people's behavior, with people being less motivated to act in ways that they think are immoral irrespective of whether those behaviors are or are not legal (Tyler, 1990). And, like the social value of legitimacy, morality is internal and shapes actions distinct from consideration of being caught and punished for wrongdoing (Tyler, 1990). What unites the study of legitimacy and morality? In both cases, the key is that people accept as their own feelings of responsibility and obligation for their actions in society.

The influence of moral values is based on the internalization of feelings of responsibility to follow principles of personal morality (see Robinson \& Darley, 1995; Tyler \& Darley, 2000). A core element of moral values is that people feel a personal responsibility to follow those values, and feel guilty when they fail to do so. Hence, moral values, once they exist are self-regulatory in character, and those who have such values are personally motivated to bring their conduct into line with their moral standards.

The importance of morality is central to the work of the psychologist Freud and the sociologist Durkheim (Tyler \& Sunshine, 2003b). As Hoffman notes: "The legacy of both Sigmund Freud and Emile Durkheim is the agreement among social scientists that most people do not go through life viewing society's moral norms as external, coercively imposed pressures to which they must submit. Though the norms are initially external to the individual and often in conflict with [a person's] desires, the norms eventually become part of [a person's] internal motive system and guide [a person's] behavior even in the absence of external authority. Control by others is thus replaced by self-control [through a process labeled internalization] (Hoffman, 1977, p. 85)." Here the self-control of concern is reflected in the influence of one's own internal moral values on one's behavior. 
As with Weber, the key issue addressed by Durkheim and Freud is the personal taking on of internal values that become self-regulating, so that people acknowledge and act on internal values that lead to deference to society, social rules, and authorities. However, in this case the values taken on are personal moral values - a responsibility to act in accord with ethical judgments about what is right and what is wrong. Although personal moral values may reflect the values of institutions and authorities with whom one deals, particularly during moral socialization during childhood, those values become internalized and viewed as one's own personal values. After that time, they are followed for internal reasons, like the value of legitimacy.

The distinction between legitimacy and morality is that, in the case of morality, legal authorities gain support for particular laws or decisions when those laws or decisions are in accord with people's personal morality. Hence, the motivation to behave in ways that are moral does not lead to support the rule of law when the public thinks that the law is inconsistent with their morality. To activate the motivation force of morality, legal authorities must be pursuing policies that are consistent with people's moral values (Sunshine \& Tyler, 2003b).

Of course, morality and legitimacy can be in conflict. A conflict between legitimacy and morality can occur with mundane and everyday practices, as when the government seems to criminalize drug use or certain sexual practices without the support of public morality (Darley, Tyler, \& Bilz, 2003), or it can involve dramatic and high-stakes conflicts, as when the government seeks to compel people to serve in wars they think are unjust, or to pay taxes to support policies they view as immoral. Unlike legitimacy, morality is not linked to the role of the authority, and its independent roots in personal ethical values mean that, while morality usually supports following laws (Tyler, 1990), the two internal forces do not always support one another.

The procedural justice approach seeks to activate morality through the fair exercise of authority. When people view the authorities as engaging in practices that the public views as being morally appropriate, that heightens their sense that legal authorities are behaving morally (Tyler \& Blader, 2005). In other words, one important set of moral values is concerned with how the police should exercise their authority, so the procedures by which the police act communicate to members of the public whether the police share their moral values (Sunshine \& Tyler, 2003b). For example, when the police engage in racial profiling, which people view as an unfair procedure, they diminish their moral authority by showing that they do not share the public's moral values about how the police should act (Tyler \& Wakslak, 2004). Legal authorities, in other words, can demonstrate that they share public morality by acting in ways that are consistent with public views about how to fairly exercise authority-e.g., by using fair procedures to make decisions.

The activation of morality also occurs in two other ways that are not related to procedural justice. First, by seeking to heighten the role of morality in 
shaping people's behavior. The psychological literature on moral development, for example, focuses on strategies for internalizing moral values in children, whose adult behavior is then shaped by their moral judgments (Eisenberg, Reykowski, \& Staub, 1989; Kurtines \& Gewirtz, 1984; Lickona, 1976; Rest, 1986). The literature on moral development suggests that most children develop moral values, but that development is not inevitable and it is possible for adults not to develop moral values during childhood. Hence, the degree to which a child develops moral values, which shape their adult behavior, has implications for the functioning of the law.

The law can also enlist people's moral values as a motivational force supporting deference to the law by pursuing ends that people view as moral. For example, Robinson and Darley (1995) point to discrepancies — real and imagined-between the law and people's moral values. They argue that the law is less likely to be able to call upon people's moral motivations to support the legal system when its values are viewed as discrepant from those of the public. Hence, the law can engage moral values when and if the law is consistent with the moral values held by the public (Tyler, 2005).

\section{Procedural Justice and Restorative Justice}

The procedural justice approach shares a core similarity with the restorative justice approach. The restorative justice approach argues that the goal when dealing with people who may have broken social rules should be to seek ways to heighten the future motivations that those people have to engage psychologically and behaviorally in society. This engagement includes developing or becoming more committed to social values that promote self-regulation, and consequently adhering more closely to laws and social regulations in the future. In other words, both approaches view one important goal when dealing with people as being to create better community members.

Restorative justice argues that the social goal that should dominate reactions to transgressions is to resolve the dispute via reintegrative shaming (Braithwaite, 2002). Reintegrative shaming combines strong disapproval of bad conduct with respect for the person who committed those bad acts. The goal is restoring victims, offenders, and the community. In the case of offenders, the goal is to encourage feelings of shame regarding one's bad acts, accepting responsibility, and sincerely apologizing. This restores the dignity of offenders. Key to this process is the social connection that people feel to their family, friends, and community. These parties are present at restorative justice hearings, along with the victim and their family and friends. All of those present are involved in reconnecting the offender to their sense of responsibility to their community. The goal of this reconnection is to encourage feelings of responsibility to family, friends, and community that will enhance commitment to self-regulatory actions. This commitment, in turn, works against future transgressions of the law. 
This restorative justice argument mirrors the concern in procedural justice research with developing informal and formal legal procedures that have the effect of strengthening the influence of social values on people's law-related behavior. This can occur because people become more connected to their feelings of responsibility to others in their community, because they become more motivated to follow their moral principles, or because they feel greater obligation to defer to societal authorities and institutions. All of these internal motivations facilitate future law abidingness.

The influence of morality and legitimacy on law-related behavior has already been noted (Tyler, 1990). This influence supports the argument that procedural justice influences law-abiding behavior. Evidence also supports the facilitative role of restorative justice conferences (Sherman, 1999). Studies suggest that, at least with some types of crimes, experiencing a restorative justice conference leads to greater deference to law in the future (Nugent, Williams, \& Umbreit, 2003; Paulson, 2003). This suggests that such conferences build internal motivation to accept the law and the decisions of legal authorities.

\section{The Mechanisms Involved}

While each of the three approaches outlined seeks to active people's internal motivations, there are important differences in the focus of these three bodies of research. The procedural justice approach seeks to activate feelings of responsibility and obligation to authorities. Research makes clear that people feel that authorities are entitled to be obeyed when they exercise their authority using fair procedures (Tyler, 1990). Further, the use of fair procedures leads people to feel that the authorities share their moral values (Sunshine \& Tyler, 2003b). In both cases, the key psychological mechanism is the activation of internal social values, which then motivate self-regulatory behavior.

The moral value literature focuses on the development of strong moral values during the childhood socialization process. Those values then guide adult actions, leading people to be motivated to engage in actions that are consistent with their moral values. When they fail to do so, they feel the emotion of guilt. Guilt arises when one has engaged in actions inconsistent with one's self-image (Tangney \& Dearing, 2002).

Finally, the restorative justice approach focuses on engaging people's feelings of responsibility to their family and community. It argues that when people feel that they have damaged their image in the eyes of others, this has destructive consequences for themselves. People feel the damaging emotion of shame (Ahmed, Harris, Braithwaite, \& Braithwaite, 2001; Scheff, 1997). By seeking to separate out and repair the damaged self while condemning the destructive action, the restorative conference has the goal of building positive connections to one's family, friends, and community. Those social bonds then sustain ongoing motivations to 
engage in socially appropriate behaviors that earn the approval of others (Tangrey \& Dearing, 2002).

Hence, each of these models views an important goal as being to find ways to encourage desirable social behavior in the long term by activating people's internal self-regulatory motivations. Irrespective of whether the relevant motivations are obligation to authorities, responsibility for following moral values, or social bonds with others, each provides the basis upon which a self-regulatory society can be developed.

Of course, obligation, shame, and guilt are not identical psychological motivations, and one question is whether one approach is more efficacious than others. Empirical research has not compared these various models, either to see if one is more influential than others or to explore whether they are separate psychological dynamics. The psychological mechanisms underlying the models underlined are generally unexamined in the literature. It is clearer that these approaches are effective than it is why they are effective.

\section{Changing the Culture of Social Control}

Irrespective of which of these models is the focus of concern, the general message is the same. The current focus on punishment as a mechanism through which to shape the behavior of both wrongdoers and people in general has had negative effects on society, particularly American society. It has led to a dramatic growth in the American prison population, and soured the relationship between the law, legal authorities, and members of society. It has had a particularly negative impact on the minority community.

The goal of the procedural justice model, like the restorative model, is to articulate a different approach to managing issues of social order and social control. Both models, like the moral socialization model, argue that most people have social values and social bonds that motivate them to follow most rules most of the time. It is this motivational force that generally sustains societies, freeing legal authorities to focus on managing that small subset of people who lack such values and ties (Ayres \& Braithwaite, 1992).

The procedural justice model focuses on everyday rule following. It suggests that the key to motivating compliance based on internal social values is to maintain the legitimacy of the law and of legal authorities. To do so, legal authorities need to focus on exercising legal authority fairly. That procedural fairness encourages people to feel that the law is legitimate and ought to be obeyed. As a consequence, people become self-regulatory, and follow the law as a consequence of their own internal values (Tyler, 2005, 2006; Tyler \& Blader, 2005).

In addition, the procedural justice model has implications for people's personal experiences with law. When people come before the law, for example, because they have broken some law and appear in court or deal with a police officer, there are 
several goals that are important. One is to deal with appropriate punishment or restitution. The other, emphasized by the procedural justice model, is to encourage feelings of legitimacy among those dealing with the legal system. In other words, each encounter that people have with authorities is an instance of civic education, which teaches people about the law. Evidence suggests that even when people are being sanctioned by the law, they are also being educated about the nature of the law and legal authorities (Tyler \& Huo, 2002).

One of the most striking examples of the procedural justice approach is provided by Paternoster, Brame, Bachman, and Sherman (1997). This study examines the long-term consequences of people's experiences with the police when the police are called to deal with domestic violence complaints. In such situations, the police direct their actions toward the offender-typically the man in the situation. But, what actions matter in the long term? The findings of this study suggest that if the police treat the offender fairly, that person is likely to refrain from further abuse in the future. In other words, the police can motivate people to self-regulate in the future by treating them with fairness when they deal with them.

This study illustrates the paradigm underlying the procedural justice approach. It suggests the possibility of process-based regulation. By using fair processes, the police encourage the activation of the social values that sustain law-abiding behavior over time. In addition, as Tyler and Huo (2002) demonstrate, fair procedures encourage immediate deference, lessen the likelihood of spirals of conflict, and increase the legitimacy of the police and courts. Hence, fair procedures have both immediate and long-term positive consequences.

One concern about the range of the procedural justice approach is whether or not it applies to the poor, the disenfranchised, and those who are less likely to buy into societies' values. Tyler and Huo (2002) address this question directly by comparing the reactions of white and minority members of the public to their personal experiences with the police and courts. They find that the procedural justice model is an equally strong predictor of reactions within both groups. In fact, although there are large race-based differences in reactions to the police and courts, those differences disappear when procedural justice variables are included in the model. Further, Tyler and Huo (2002) look specifically at the group of respondents typically considered most problematic by law enforcement-young, minority, males - and find that the members of this group are also strongly motivated by procedural justice judgments.

Like the procedural justice model, the restorative justice model also deals with legal procedures that are initiated when someone breaks a legal rule. And the goal of restorative procedures is also to further people's loyalty to and adherence with legal rules in the future. In the case of restorative justice, the restorative justice conference seeks to motivate such immediate and future behavior by separating the "good" person from their "bad" conduct. The conferences then seek to both deal with the consequences of the bad conduct and, separately, to connect the good 
person to their motivation to behave in ways that win respect from their family, friends, and community. It is this connection with one's favorable self-image that motivates compliance in the future.

Hence, both of these models argue for the possibility of a society that focuses on punishing wrongdoing, but upon creating and maintaining people who are motivated by their own internal values and social bonds to self-regulate. As Tyler and Huo (2002) argue, the success of such efforts builds momentum over time. They demonstrate that those people who view the law as legitimate respond to that view by evaluating their personal experiences with the police and courts in more process-oriented ways. Hence, the existence of legitimacy makes it easier for policing to occur based upon the use of fair procedures. This, in turn, further enhances the possibility of creating legitimacy.

Many of the ideas outlined here are not only implications of a procedural justice or restorative justice approach to policing. They are also part of the community policing and problem-oriented policing approaches to policing. Those approaches emphasize police efforts to move beyond reacting to already committed crimes to making efforts to proactively work with communities to solve community problems.

Studies suggest that people value having the police talk to citizens and cooperate with citizens to solve community problems (Sunshine \& Tyler, 2003a). They support more bike and pedestrian patrols because they "like to perceive the police as friends and helpers and they would support endeavors to improve the work of the police force much in the sense of what community and problem-oriented policing propose (Weitekamp, Kerner, \& Meier, 1996, p. 16)." Similarly a study of public complaints about the police similarly showed that the two primary reasons for complaining were "rude, arrogant, unfriendly, over-casual treatment (38\%)" and "unreasonable, unfair behavior (46\%)" (see Skogan, 1994).

These findings suggest that people would like to improve the relationship between citizens and the police, a core concern of problem-oriented and community policing. In fact, Weitekamp et al. (1996) propose a restorative problem-solving police prevention program that views reconciliation between victims, the community as a whole, and perpetrators as a key goal. They argue that four groups - the police, the community, the offender, and the victim-should be involved in efforts to reconcile following wrongdoing. All of these groups should be jointly concerned to make their community safer, reduce fear, prevent future crime, improve the quality of life, and increase interpersonal harmony among the people in communities.

The comparison of these approaches makes clear that there are several conceptual issues underlying the distinctions among restorative, problem-oriented, and community policing. One issue is what the appropriate responsibilities of the police should be. Traditionally the police are responsible for enforcing the law by regulating public behavior and apprehending those who break laws. Those people 
are evaluated and potentially punished by the courts. Recently there have been arguments for an expanded police role in helping to solve community problems, and help communities to solidify themselves as communities. These arguments stem in part from the recognition that the police cannot effectively control crime without community assistance (Sampson \& Bartusch, 1998; Sampson, Raudenbush, $\&$ Earls, 1997), and in part from the suggestion that at least some members of the public would like for the police to have a broader role in the community than just rule enforcement and crime control.

A second issue is who should deal with rule breaking. Within modern societies, the state has the central authority for deciding how to react to rule breaking, with the police and courts deciding who to arrest, how to determine wrongdoing, and how to punish for wrongdoing. This has led to a variety of types of discontent. The victims of crime feel excluded from the determination of punishment, and would like to have a greater role in deciding how to deal with criminals. Communities would also like a greater role in part, because they feel that the punishments of the formal legal system depart from the communities' feelings about what is right and what is wrong (Robinson \& Darley, 1995). These groups have argued for greater opportunities to participate in determinations of how to deal with crime and criminals.

Finally, there is the question of how crime should be dealt with. The current legal system emphasizes determinations of guilt and the application of punishment. However, approaches such as the restorative justice model argue for the value of seeking to rehabilitate offenders-emphasizing the encouragement of future law-abiding behavior as the goal over punishment for past wrongs. This goal leads to efforts to work with the families and communities affected by the crime to encourage the criminal to come into compliance with community norms and values. Restorative justice itself is a model for the goal that should shape reactions to wrongdoing. It does not speak to the issue of who- the community, the police, the courts-should have the authority to manage responses to deviant behavior. In a series of experiments conducted in Australia, for example, the police managed restorative justice sessions (Braithwaite, 1989, 2002). However, in many of the traditional dispute resolution approaches from which restorative justice draws its inspiration, the community and community leaders were the key authorities. The restorative justice approach is a model for how to react to wrongdoing, rather than a model of policing, but it can be applied to policing if the police adopt a restorative justice approach to their dealings with wrongdoers.

Procedural justice does not focus on shame. It focuses on obligation and responsibility. However, both shame and obligation are internal motivations for selfregulatory behavior. In fact, we can combine these with a third motivation noted earlier in the discussion-morality - to identify three self-regulatory motivations. These are shown in Table 1. While all three are united in their goal of activating people's internal values, they focus on different issues. Procedural justice focuses 
Table 1. Self-regulatory Motivations.

\begin{tabular}{clc}
\hline Model & Focus & Motivation that is activated \\
Procedural justice models & $\begin{array}{l}\text { Legitimacy } \\
\text { of authority }\end{array}$ & Obligation \\
Restorative justice models & $\begin{array}{l}\text { Relationships to } \\
\text { others }\end{array}$ & Shame \\
Moral development models & $\begin{array}{l}\text { Principles of } \\
\text { right and wrong }\end{array}$ & Guilt \\
\hline
\end{tabular}

on feelings of obligation and responsibility to authorities. Restorative justice is concerned with people's relationships to others and the shame that occurs when people disappoint others. Moral values lead to guilt when a person violates their own personal standards of right and wrong.

In contrast, sanction-based approaches undermine and lessen the influence of people's values on their behavior. Social psychologists make clear that one consequence of focusing on incentives and sanctions within a given situation is that people's behavior becomes more strongly linked to those instrumental factors. If people have internal motivations, such as social values, the role of those values in shaping the behavior is "crowded out," and becomes less important (Deci, 1975; Frey, 1994). In the long run, the use of sanction-based approaches has the consequence of undermining the influence of social values on behavior. The use of sanctions today means that greater and more frequent sanction use will be required in the future.

\section{Can These Models Be Implemented?}

As noted at the beginning of this discussion, there is evidence that these models can be effective. But, can they be implemented? One problem that might lie in the way are public views about how to respond to wrongdoing. These views are linked to public judgments about whether people can be changed and, if so, how best to achieve change. In the 1960s, there was a strong belief that people could be rehabilitated (Tyler et al., 1997). However, the greater punitiveness already noted might suggest that this belief has changed among Americans.

Tyler and Boeckmann (1997) found that people in a sample of Californians indicated that they did not feel that people could be changed when they felt that wrongdoers lacked core moral and social values and social bonds that could be appealed to and activated among wrongdoers. The feeling that there were no 
Table 2. What Policies Are Effective in Lowering Crime?

\begin{tabular}{lc}
\hline & Yes $(\%)$ \\
\hline Will this policy Be Effective in Lowering Crime & 55 \\
Putting criminals in prison for life after three felonies. & 44 \\
Using the death penalty more often? & 70 \\
Publishing names of criminals in their communities so that their & 51 \\
$\quad$ neighbors and friends are aware of their crimes? & 85 \\
Requiring people to apologize? & 76 \\
Using schools to encourage the development of values such as & \\
respect and responsibility to follow rules? & 95 \\
Is it difficult to rehabilitate burglars who commit property & \\
$\quad$ crimes? & \\
Is it difficult to rehabilitate violent offenders? & \\
\hline
\end{tabular}

common core values or social bonds shared by wrongdoers and others in the community, when found, was linked to the view that American society has become culturally diverse. This belief was also linked to support for the punitive "three strikes" law, which is a clear alternative view to the idea of rehabilitation and restoration. Hence, one aspect of the challenge posed by restorative justice is to educate the public to the feasibility of these approaches to managing wrongdoing.

How serious was this potential problem? To address this question, we can look at the results of interviews of Californians conducted by Tyler and Boeckmann (1997). Those interviews were conducted in the wake of the passage of the "three strikes" initiative, a punitive measure mandating life in prison for three felony convictions. Do the views of those in this sample support the argument that people do not believe in the possibility of rehabilitation? Interestingly no. People were asked that question, as well as several related other questions on what works. Their answers are shown in Table 2 . They indicate that people generally think that shaming and moral education are the most effective ways to control crime. It is striking that people, while they may support punitive measures, do not view them as particularly effective. Hence, if they felt that the conditions were such that rehabilitation and moral education were possible, people would support those approaches as being more effective.

The question that we might best ask is why people do or do not think that these different approaches are effective. Table 3 looks at the role of whether people think that there is a sense of obligation to obey the law, trust in legal authorities, moral values, and social bonds on whether they think that different approaches to dealing with crime are effective. The results suggest that people think rehabilitation will work if people have shared moral values and if they think that people trust legal authorities. They think that shaming works when there are shared social bonds, shared moral values, and feelings of obligation to obey the law. They believe that moral education works when people have shared moral values. And they think that punishment is more effective when people share moral values and social bonds, and feel an obligation to obey the law. 
Table 3. What Shapes Whether Punishment Works?

\begin{tabular}{lllll}
\hline & $\begin{array}{c}\text { Is Punishment } \\
\text { Effective? }\end{array}$ & $\begin{array}{c}\text { Is Shaming } \\
\text { Effective? }\end{array}$ & $\begin{array}{c}\text { Is Rehabilitation } \begin{array}{c}\text { Education } \\
\text { Effective? }\end{array} \\
\text { Effective? }\end{array}$ \\
\hline Do moral values exist in the community? & $.39^{* * *}$ & $.18^{*}$ & $.26^{* * *}$ & $.24^{* * *}$ \\
Do social bonds exist in the community? & $.20^{* *}$ & $.15^{*}$ & .08 & .09 \\
Are legal authorities trusted? & .05 & .01 & $.21^{* * *}$ & -.04 \\
Do people feel obligated to obey the law? & $.15^{\wedge}$ & $.17^{*}$ & .05 & .00 \\
Adj. $R^{2}$ & $21 \% * * *$ & $10 \%{ }^{* * *}$ & $13 \% * * *$ & $4 \% \%^{* * *}$ \\
\hline$\wedge p .10 ;{ }^{*} p<.05 ;{ }^{* *} p<.01 ;{ }^{* * *} p<.001$. & & &
\end{tabular}

These findings reinforce the idea that people are punitive not because they feel it is an optimal strategy. Rather, they think that the strategies outlined by the procedural justice and restorative justice models are more likely to be effective in reducing the problem of crime. That effectiveness, however, depends on the existence of shared moral values, shared social ties, and feelings of trust, confidence, and obligation toward law. Hence, one strategy is to communicate the findings outlined above, studies showing that procedural and restorative approaches do work.

\section{Summary}

The challenge for the future is to reverse an alarming trend in societies' approaches to wrongdoing. That trend is to be increasingly punitive and preoccupied with punishment for wrongdoing. This trend is especially troubling because in earlier eras the focus of much of the effort when dealing with wrongdoing was upon the rehabilitation of offenders. The procedural justice and restorative justice approaches share the underlying belief that people can be rehabilitated and that society and the legal system have a great deal to gain from focusing on the possibilities of rehabilitation and the restoration of people as law-abiding members of society. Further, both models have provided compelling empirical evidence in support of their arguments. These findings aside, it is clear that efforts to change the current paradigm for dealing with wrongdoing must involve substantial changes in public views about both society and human motivation.

\section{References}

Ahmed, E., Harris, N., Braithwaite, J., \& Braithwaite, V. (2001). Shame management through reintegration. Cambridge, UK: Cambridge University Press.

Ayres, I., \& Braithwaite, J. (1992). Responsive regulation: Transcending the deregulation debate. Oxford, UK: Oxford University Press.

Braithwaite, J. (1989). Crime, shame, and reintegration. Cambridge, UK: Cambridge University Press. 
Braithwaite, J. (2002). Restorative justice and responsive regulation. Oxford, UK: Oxford University Press.

Darley, J., Tyler, T. R., \& Bilz, K. (2003). Enacting justice: The interplay of individual and institutional perspectives. In M. A. Hogg \& J. Cooper (Eds.), Handbook of social psychology. London: Sage.

Deci, E. L. (1975). Intrinsic motivation. New York: Plenum.

Eisenberg, N., Reykowski, J., \& Staub, E. (1989). Social and moral values. Hillsdale, NJ: Erlbaum.

Ellsworth, P. C., \& Gross, S. R. (1994). Hardening of the attitudes: Americans' views on the death penalty. Journal of Social Issues, 50, 19-52.

Foglia, W. C. (1997). Perceptual deterrence and the mediating effect of internalized norms among inner-city teenagers. Journal of Research in Crime and Delinquency, 34, 414-443.

French, J. R. P., \& Raven, B. (1959). The bases of social power. In D. Cartwright (Ed.), Studies in social power. Ann Arbor: University of Michigan Press.

Frey, B. S. (1994). How intrinsic motivation is crowded in and out. Rationality and Society, 6, 334-352.

Garland, D. (2001). The culture of control: Crime and social order in contemporary society. Chicago: University of Chicago Press.

Gold, M. (1999). The complete social scientist: A Kurt Lewin reader. Washington, DC: American Psychological Association.

Grasmick, H. G., \& Bursik, R. J. (1990). Conscience, significant others, and rational choice. Law and Society Review, 24, 837-861.

Haney, C., \& Zimbardo, P. (1998). The past and future of U.S. prison policy: Twenty-five years after the Stanford Prison Experiment. American Psychologist, 53, 709-727.

Hoffman, M. L. (1977). Moral internalization: Current theory and research. Advances in Experimental Social Psychology, 10, 85-133.

Kelman, H. C., \& Hamilton, V. L. (1989). Crimes of obedience. New Haven, CT: Yale.

Kurtines, W. M., \& Gewirtz, J. L. (1984). Morality, moral behavior, and moral development. New York: Wiley.

Lickona, T. (1976). Moral development and behavior. New York: Holt, Rinehart, Winston.

MacCoun, R. J. (1993). Drugs and the law: A psychological analysis of drug prohibition. Psychological Bulletin, 113, 497-512.

Meares, T. L. (2000). Norms, legitimacy, and law enforcement. Oregon Law Review, 79, 391-415.

Merelman, R. J. (1966). Learning and legitimacy. American Political Science Review, 60, 548561.

Nagin, D. S. (1998). Criminal deterrence research at the outset of the twenty-first century. In M. Tonry (Ed.), Crime and justice (Vol. 23, pp. 1-42). Chicago: University of Chicago Press.

Nagin, D. S., \& Paternoster, R. (1991). The preventive effects of the perceived risk of arrest. Criminology, 29, 561-585.

Nagin, D. S., \& Pogarsky, G. (2001). Integrating celerity, impulsivity and extralegal sanction threats into a model of general deterrence. Criminology, 39, 865-892.

Nugent, W. R., Williams, M., \& Umbreit, M. S. (2003). Participation in victim-offender mediation and the prevalence and severity of subsequent delinquent behavior. Utah Law Review, 2003(1), 137-166.

Paternoster, R. (1987). The deterrent effect of the perceived certainty and severity of punishment. Justice Quarterly, 4, 173-217.

Paternoster, R. (1989). Decisions to participate in and desist from four types of common delinquency. Law and Society Review, 23, 7-40.

Paternoster, R., Brame, R., Bachman, R., \& Sherman, L. W. (1997). Do fair procedures matter?: The effect of procedural justice on spouse assault. Law and Society Review, 31, 163-204.

Paternoster, R., \& Iovanni, L. (1986). The deterrent effect of perceived severity. Social Forces, 64, 751-777.

Paternoster, R., Saltzman, L. E., Waldo, G. P., \& Chiricos, T. G. (1983). Perceived risk and social control: Do sanctions really deter? Law and Society Review, 17, 457-479.

Poulson, B. (2003). A third voice: A review of empirical research on the psychological outcomes of restorative justice. Utah Law Review, 2003(1), 167-204.

Reiss, A. (1971). The police and the public. New Haven, CT: Yale.

Rest, J. R. (1986). Moral development: Advances in research and theory. New York: Praeger. 
Roberts, J. V., \& Stalans, L. J. (2000). Public opinion, crime, and criminal justice. Boulder, CO: Westview.

Robinson, P. H., \& Darley, J. (1995). Justice, liability, and blame. Boulder, CO: Westview.

Sampson, R. J., \& Bartusch, D. J. (1998). Legal cynicism and (subcultural?) tolerance of deviance. Law and Society Review, 32, 777-804.

Sampson, R. J., Raudenbush, S. W., \& Earls, F. (1997). Neighborhoods and violent crime. Science, $277,918-924$.

Scheff, T. J. (1997). Emotions, the social bond, and human reality. Cambridge, UK: Cambridge University Press.

Sherman, L. (1993). Defiance, deterrence, irrelevance: A theory of the criminal sanction. Journal of Research in Crime and Delinquency, 30, 445-473.

Sherman, L. (1998). Alternative prevention strategies and the role of policing. Presentation at a conference on "Beyond incarceration." Cambridge, MA: Harvard Trade Union Program.

Sherman, L. (1999). Consent of the governed. Presentation at Hebrew University.

Skogan, W. G. (1994). Contacts between police and public. London: A home office research and planning unit report.

Sunshine, J., \& Tyler, T. R. (2003a). The role of procedural justice and legitimacy in shaping public support for policing. Law and Society Review, 37, 555-589.

Sunshine, J., \& Tyler, T. R. (2003b). Moral solidarity, identification with the community, and the importance of procedural justice. Social Psychology Quarterly, 66, 153-165.

Tangney, J. P., \& Dearing, R. L. (2002). Shame and guilt. New York: Guilford.

Tyler, T. R. (1990). Why people obey the law: Procedural justice, legitimacy, and compliance. New Haven, CT: Yale University Press.

Tyler, T. R. (1997). Citizen discontent with legal procedures. American Journal of Comparative Law, 45, 869-902.

Tyler, T. R. (1998). Public distrust of the law. University of Cincinnati Law Review, 66, 847-876.

Tyler, T. R. (2001). Public trust and confidence in legal authorities. Behavioral Sciences and the Law, $19,215-235$.

Tyler, T. R. (2003). Procedural justice, legitimacy, and the effective rule of law. In M. Tonry (Ed.), Crime and justice: A review of research (pp. 283-358). Chicago: University of Chicago Press.

Tyler, T. R. (2004). Procedural justice. In A. Sarat (Ed.), The Blackwell companion to law and society (pp. 435-452). Malden, MA: Blackwell.

Tyler, T. R. (2006). Legitimacy and legitimation. Annual Review of Psychology, 57, 375400.

Tyler, T. R. (2005). Promoting employee policy adherence and rule following in work settings: The value of self-regulatory approaches. Brooklyn Law Review, 70, 1287-1312.

Tyler, T. R., \& Blader, S. (2000). Cooperation in groups. Philadelphia: Psychology Press.

Tyler, T. R., and Blader, S.L. (2005). Can businesses effectively regulate employee conduct?: The antecedents of rule following in work settings. Academy of Management Journal, 48, 11431158.

Tyler, T. R., \& Boeckmann, R. J. (1997). Three strikes and you are out, but why? The psychology of public support for punishing rule breakers. Law and Society Review, 31, 237-265.

Tyler, T. R., Boeckmann, R. J., Smith, H. J., \& Huo, Y. J. (1997). Social justice in a diverse society. Boulder: Westview.

Tyler, T. R., \& Darley, J. (2000). Building a law abiding society. Hofstra Law Review, 28, 707739.

Tyler, T. R., \& Huo, Y. J. (2002). Trust in the law: Encouraging public cooperation with the police and courts. New York: Russell-Sage.

Tyler, T. R., \& Wakslak, C. (2004). Profiling and the legitimacy of the police: Procedural justice, attributions of motive, and the acceptance of social authority. Criminology, 42, 1342 .

Weber, M. (1968). Economy and society. (G. Roth and C. Wittich, Eds.). Berkeley: University of California Press.

Weitekamp, E. G. M., Kerner, H., \& Meier, U. (1996). Problem solving policing. Paper, International Conference on Problem Solving Policing as Crime Prevention, Stockholm, Sweden. 
Whitman, J. Q. (2003). Harsh justice: Criminal punishment and the widening divide between American and Europe. Oxford, UK: Oxford University Press.

TOM R. TYLER is University Professor of Psychology at New York University. His research examines the dynamics of authority in groups and organizations. His books include: The Social Psychology of Procedural Justice (1988); Why People Obey the Law (1990); Social Justice in a Diverse Society (1997); and Trust in the Law (2002). 